\title{
PENGARUH RISIKO KREDIT, RISIKO SOLVABILITAS DAN KUALITAS AUDIT TERHADAP PROFITABILITAS PERUSAHAAN SERTA IMPLIKASINYA TERHADAP KUALITAS LABA
}

\author{
Pardomuan Ritonga \\ Institut Teknologi Dan Bisnis Ahmad Dahlan, Jakarta - Indonesia \\ pardomuanritonga1974@gmail.com
}

Diterima 8 April 2020

Disetujui 20 Mei 2020

\begin{abstract}
This research aims to analyzethe influence of financial risk i.e. credit and solvency risk as long as audit quality on the firm's profitability and implications with earnings quality. This type of research is quantitative. The research population is sub-sectors of general insurance listed in the Indonesia Stock Exchange in 2014-2018. The sampling method using purposive sampling technique is counted 10 companies. The method of analysis using linear regression analysis and sobel test. These results indicate that financial risk has significant effect simultaneously on the profitability of firms as long as financial risk and audit quality has no significant effect simultaneously on the earnings quality. The partial test results showed that solvency risk and audit quality have a negative effect while credit risk has no significant effect to the profitability of firms. However, credit and solvency risk as long as audit quality have no indirect effect to the earnings quality through profitability of firms.
\end{abstract}

Keywords: solvency risk, profitability of firms, earnings quality value

\section{PENDAhUluan}

Perusahaan asuransi merupakan salah satu pilar usaha pada Industri Keuangan Non-Bank (IKNB) yang berkontribusi dan sangat siap menghadapi tantangan revolusi industri 4.0. Industri ini merupakan bagian yang terintegrasipada kinerja agen asuransi dengan serangkaian proses atau paperwork yang cukup kompleks, hadirnya era 4.0 yang diimplementasikan ke konsep digitalisasi, modernisasi dan digitalisasi jalur proses antara perusahaan-agen-nasabah (Baskoro, 2018). Usaha perasuransian sebagai jasa pengelolaan risiko menjalankan aktivitas utamaantara lainstrategi penetapan harga,penanganan klaim,underwriting, dan reinsurance managementyang harus dikelola sebaik-baiknya dalam rangka perusahaan mempertahankan kelangsungannya (Wani \& Dar, 2015). 


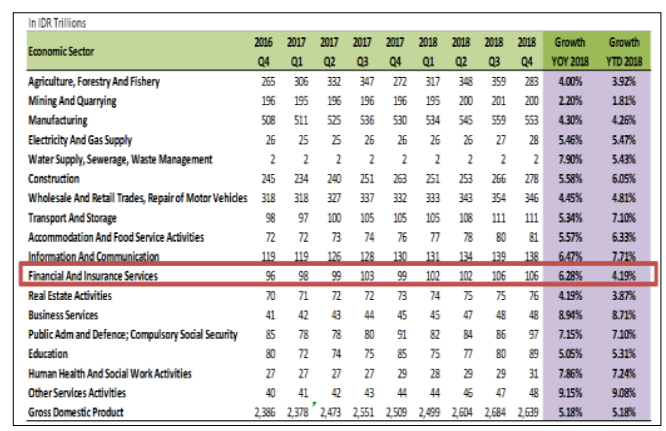

(Sumber: SEKI Bank Indonesia, 2019)

\section{Gambar 1. Pertumbuhan Ekonomi Indonesia per Sektor pada Harga Konstan}

Sektor Keuangan dan Jasa Asuransi mengalami pertumbuhan GDP tahun 2018 sebesar 4,19 persen YTD atau sebesar 6,28 persen YOY. Trend positif ini menempatkan sektor jasa keuangan berdasarkan GDP per kwartal dan forecast yang terus mengalami peningkatan pangsa pasar Indonesia seiring dengan peningkatan kesadaran masyarakat atas manfaat produk asuransi dalam strategi pengelolaan risiko yangpemegang polis (Bank Indonesia, 2019). Menurut Ketua Asosiasi Asuransi Jiwa Indonesia (AAJI), adanya program dari regulator OJK melalui gerakan inklusi keuangan kepada masyarakat dalam mengedukasi pengetahuan terkait risiko-risiko yang melekat pada nasabah asuransi atau aset-aset yang dimiliki dan dikelola melalui agen perusahaan asuransi. Atas produk dan layanan asuransi tersebut juga ditandai dengan potensi pasar yang sangat besar di Indonesia dengan pertumbuhan premi asuransi jiwa pada hingga kuartal ketiga 2017 mengalami pertumbuhan 37,76 persen dengan total investasi sebesar Rp486,5 triliun (Al Hafiz, 2018).

Setiap perusahaan asuransi harus menyampaikan laporan tingkat solvabilitas dengan menggunakan metode risk-based capital (RBC) sebagaimana tertuang pada Pasal 3 POJK No.71 tahun 2016 atas tingkat solvabilitas paling rendah 100 persen dari risiko modal minimum berbasis risiko (MMBR) (OJK, 2016). Ketidakmampuan dalam pemenuhan klaim sebelumnya atas dispersi arus kas bersih dan kewajiban jangka pendek menjadi bagian dari pengelolaan likuiditas perusahaan dalam konteks risiko kebangkrutan tunai (cash insolvency) (Wani \& Dar, 2015). Perusahaan asuransi mengumpukan dana dari nasabah (tertanggung) berupa premi dalam rangkamenanggulangi risiko dari aktivitas operasionalnya. Premi yang terkumpul harus dikelola dengan baik agar perusahaan mendapatkan laba yang optimaldan memenuhi segala kewajiban atas nasabahnya (Nurfadila, Hidayat, \& Sulasmiyati, 2015).Perusahaan asuransi mengasuransikan sejumlah risiko yang ditanggung untuk mengurangi risiko kebangkrutan jika terjadi kerugian besar walaupun reasuransi dapat meningkatkan stabilitas perusahaan asuransi melalui penyebaran risiko, pencapaian persyaratan solvabilitas, keseimbangan profil risiko, dan pertumbuhan kapasitas penjaminan (Worku \& Asmare, 2018). Pasal 4 POJK No.71 tahun 2016 memperkuat dengan perhitungan kebutuhan modal paling sedikit adalah risiko likuiditas, risiko kredit, risiko pasar, risiko asuransi, dan risiko operasional (OJK, 2016).

Faktor penting lainnya untuk pengelolaan modal berbasis risiko dan profitabilitas melalui sistem supervisi dari organ komite audit, audit internal dan eksternal untuk lebih memantau ketentuan keuangan yang disyaratkan oleh Pemerintah berdasarkan Peraturan Otoritas Jasa Keuangan (POJK) Nomor 2 Tahun 2014 dalam penunjukkan auditor eksternal 
(Merawati \& Hatta, 2014), kondisi di atas menjadi bukti bahwa kualitas audit menjadi prasyarat untuk memastikan kinerja keuangan perusahaan asuransi.

Tantangan pada sektor industri asuransi ini dapat dijadikan peluang di Indonesiayang saat ini masih terbilang memiliki penetrasi sangat rendah dibandingkan dengan negara tetangga seperti Malaysia dan Singapura setelah Indonesia bergabung menjadi bagian dari masyarakat MEA sejak tahun 2016 (Intan, 2019). Kenaikan atau penurunan harga saham di bursa, khususnya untuk perusahaan asuransi yang terdaftar di Bursa Efek Indonesia (BEI) sangat dipengaruhi oleh baik atau buruknya kinerja perusahaan yang digambarkan dengan rasio profitabilitas.

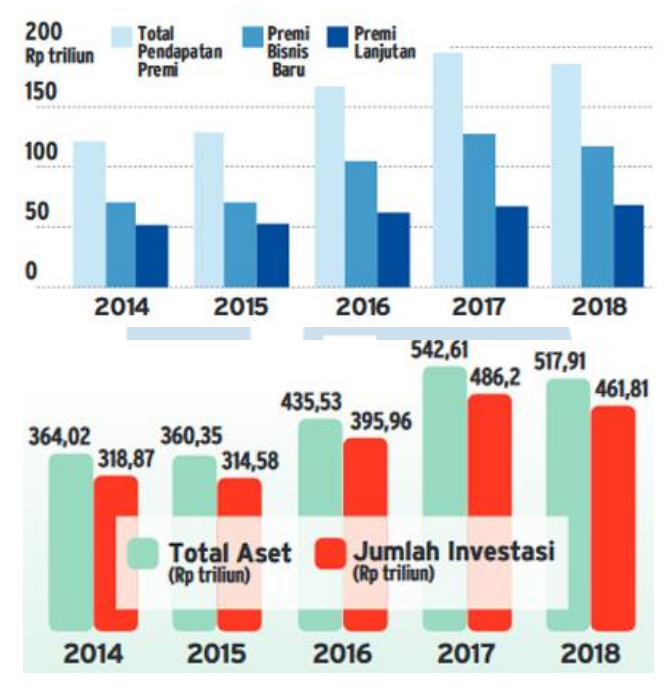

(Sumber: https://finansial.bisnis.com/, 2019)

\section{Gambar 2. Total Pendapatan dan Nilai Aset dibandingkan dengan Jumlah Investasi Industri Asuransi}

Data total pendapatan dan indikator kinerja industri asuransi selama periode 2014-2018 mencatat bahwa terjadi penurunan indikator kinerja dan nilai aset pada tahun 2018 sebesar Rp24,7 triliun dan juga penurunan investasi sebesar Rp24,39 triliun dibandingkan dengan tahun 2017, hal ini menjadi perhatian bagi industri asuransi dibandingkan periode 2014 hingga 2017 yang mengalami peningkatan yang cukup signifikan. Penurunan hasil total pendapatan dan nilai aset ini berdampak pada pengukuran rasio profitabilitas untuk mengukur keberhasilan dari kinerja perusahaan asuransi. Penurunan kinerja yang terjadi diantaranya indikator yang diantaranya adalah pendapatan premi, premi bisnis baru dan lanjutan serta nilai aset (impairment of assets) dibandingkan dengan jumlah investasi (Aldila, Jatmiko, \& Hana, 2019).Industri pada sektor keuangan asuransi masih cukup optimis tumbuh sepanjang tahun 2019. Menurut Direktur eksekutif Asosiasi Asuransi Umum Indonesia melaporkan bahwa pendapatan premi bruto Rp39,95 triliun hingga Juni 2019 dengan persentase pertumbuhan 20,6 persen dibandingkan Rp33,31 triliun pada Juni 2018 (Dalimunthe, 2019). 
Beberapa temuan penelitian dari kalangan akademis dalam kurun waktu 10 tahun terakhir telah menguji risiko kredit dengan hasil yang cukup beragam pada industri perbankan maupun asuransi. Asumsi risiko kredit dapat dipahami sejauh mana kemampuan dalam menyerap kerugian dan pengembalian minimun yang diharapkan dapat diterima untuk tingkat risiko tertentu termasuk obligasi, risiko gagal bayar, pinjaman utang yang dipertanggungkan dan peran debitor (The National Bank of Ethiopia (NBE), 2010). Risiko kredit berpengaruh negatif terhadap profitabilitas perusahaan asuransi yang melibatkan 8 perusahaan asuransi dalam kurun 16 periode pengamatan (Sisay, 2017). Risiko kredit juga diungkap dengan arah pengaruh negatif terhadap profitabilitas yang melibatkan 14 bank komersial dalam kurun 6 periode pengamatan (Olalekan, Olumide, \& Irom, 2018) serta temuan risiko kredit juga yang berpengaruh negatif studi empiris pada 22 perusahaan perbankan yang listing di BEI Tahun 2011-2015 dengan proksi non-performing Loan (NPL) (Suryo, Rahayu, \& Nurbaiti, 2016). Oleh karena itu, faktor risiko kredit yang masih sedikit diteliti khususnya di Indonesia untuk menilai kesehatan perusahaan asuransi penting untuk dikaji lebih lanjut.

Risiko solvabilitas berpengaruh negatif terhadap kinerja keuangan dengan proksi solvency margin pada 24 perusahaan asuransi jiwa di India (Wani \& Dar, 2015). Pengukuran solvency risk dengan temuan arah pengaruh negatif terhadap profitabilitas perusahaan asuransi dengan pengukuran perbandingan total kewajiban dan total aset (Sisay, 2017). Pengaruh positif solvency margin terhadap profitabilitas pada 8 perusahaan yang terdaftar di Dhaka Stock Exchange (DSE) - Bangladesh (Ullah, Faisal, \& Zuhra, 2016) serta temuan analisis risk-based capital (RBC) yang berpengaruh terhadap stabilitas kesehatan perusahaan asuransi dengan proksi tingkat solvabilitas, batas tingkat solvabilitas minimum, tingkat perimbangan investasi dengan kewajiban, tingkat perimbangan premi neto dengan modal sendiri (Bogar, 2016). Penentu Kinerja Bisnis Asuransi Mikro di Ethiopia yang melibatkan 9 perusahaan asuransi selama 2009-2017 dengan pendekatan return on assets dengan hasil yang membuktikan pengaruh negatif atas faktor ketergantungan reasuransi, pertumbuhan premi, risiko penjaminan emisi serta inflasi sementara volum modal dan pangsar berpengaruh positif terhadap ROA (Worku \& Asmare, 2018).

Kinerja perusahaan yang diukur berdasarkan profitability ratio's dengan pendekatan return on assets (ROA) dan return on equity (ROE) juga telah dilakukan oleh beberapa penelitian di atas dengan hasil yang cukup konsisten atas faktor risiko keuangan yang mencakup risiko kredit dan risiko solvabilitas.Pentingnya keterlibatan mekanisme corporate governance dalam fungsi monitoring dan pengawasan struktur pengendalian eksternal yaitu auditor eksternal yang dapat menjembatani fungsi agent dan stakeholders' dalam konteks biaya keagenan untuk menghasilkan kualitas audit yang baik.BerdasarkanPOJK No.71/POJK.05/2016 tentang kesehatan perusahaan Asuransi dan perusahaan Reasuransi, pencapaian rasio solvabilitas minimal adalah 100 persen atas target internal yang sekurangkurangnya adalah 120 persen dari MMBR. Temuan penelitian yang membuktikan pengaruh positif kualitas audit terhadap kesehatan keuangan perusahaan dan dampaknya terhadap profitabilitas dalam pengawasan atas kegiatan operasional perusahaan yang melibatkan 11 perusahaan asuransi periode 2012 (Merawati \& Hatta, 2014) Oleh karena itu, faktor kualitas audit untuk menilai kesehatan perusahaan asuransi di Indonesia juga penting untuk dikaji lebih lanjut.

Kualitas laba yang dilaporkan yang ditinjau dari tingkat profitabilitas sebagai faktor penghubung juga belum banyak dilakukan penelitian di Indonesia. Pengaruh risiko keuangan 
dengan pengukuran leverage yang tidak membuktikan pengaruhnya terhadap perataan laba yang melibatkan 150 data observasi selama tahun 2013-2015 pada industri manufaktur sehingga perusahaan yang memiliki nilai risiko keuangan yang lebih besar tidak cenderung untuk melakukan tindakan perataan laba (Lathifah, Hidayati, \& Malikah, 2018). Hasil pengujian solvabilitas yang diproksikan dengan risk-based capital berpengaruh positif dan signifikan terhadap laba perusahaan reasuransi dengan proksi ROA (Suud, 2016). Temuan penelitian lainnya yang membuktikan pengaruh positif book-tax differences terhadap earnings quality yang melibatkan faktor kualitas auditdengan hasil yang tidak memediasi pengaruh book-tax differences terhadap audit quality yang juga melibatkan 77 perusahaan manufaktur selama tahun 2013-2017 (Ritonga, 2019). Faktor penentu risiko keuangan yang cukup banyak digunakan peneliti untuk menilai kinerja perusahaan adalah rasio profitabilitas dengan proksi return on assets.

Penetapan proksi laba perusahaan dalam riset ini menggunakan pengukuran return on investment (ROI) pada subjek penelitian sektor keuangan perusahaan asuransi, karena masih minimnya penelitian khususnya di Indonesia dengan melibatkan faktor-faktor risiko keuangan seperti risiko kredit dan risiko solvabilitas sehingga penelitian ini diharapkan dapat merepresentasikan kinerja dan kesehatan perusahaan serta kualitas laba yang dilaporkan atas keputusan investasi. Kualitas laba pada penelitian ini menggunakan pengukuran distribusi laba (Phillips, Pincus, \& Rego, 2003). Tujuan penelitian ini adalah merumuskan faktor risiko kredit dan risiko solvabilitas dengan menambahkan faktor kualitas audit terhadap profitabilitas perusahaan serta implikasinya terhadap kualitas laba. Pemilihan subjek penelitian ini hanya berfokus pada perusahaan asuransi kategori umum yang listing di Bursa Efek Indonesia. Saham perusahaan asuransi cukup diminati investor dalam pengambilan keputusan investasi sehubungan dengan pendapatan premi, premi bisnis baru dan premi lanjutan untuk perusahaanperusahaan asuransi atau rate of return menjadi tolok ukur suatu investasi. Tantangan pada sektor industri asuransi umum ini dapat dijadikan peluang dengan semakin maraknya atau menjamurnya produk-produk asuransi online berbasis digital untuk pangsa pasar generasi milenial

\section{TINJAUAN PUSTAKA DAN HIPOTESIS}

\subsection{Kajian Teori}

\subsubsection{Signalling Theory}

Teori sinyal (signalling theory) diperkenalkan oleh Spence pada tahun 1973 yang menjelaskan bahwa sinyal atau isyarat yang berasal dari pihak perusahaan sebagai pemilik informasi semaksimal mungkin akan memberikan informasi relevan yang dapat dimanfaatkan oleh pihak lainnya sebagai penerima informasi. Signalling theory merupakanperilaku seorang manajer yang memberikan petunjuk kepada investor atas prospek perusahaan di masa yang akan datang (Brigham \& Houston, 2014). Sinyal dimaksud dapat berupa informasi bahwa perusahaan tersebut dinyatakan lebih baik dari perusahaan lain.Informasi keuangan yang dirilis oleh perusahaan-perusahaan yang listing di Bursa Efek Indonesia (BEI) akan memberikan sinyal bagi investor yang terlebih dahulu dilakukan analisis dan interpretasi untuk pengambilan keputusan investasi.

\subsubsection{Risk-based capital (RBC)}

Risk-based capital (RBC) sebagai instrumen untuk mengukur solvabilitas atas rasio kecukupan modal menjadi tolok ukur atas kepentingan nasabah khususnya pada perusahaan- 
perusahaan asuransi yang menjadi salah satu objek penting dalam penelitian ini. Menurut Pasal 3 ayat (2) dan (3)Salinan POJK menetapkan bahwa target tingkat solvabilitas internal serendah-rendahnya adalah 120 persen dari MMBR berdasarkan profil risiko perusahaan serta mempertimbangkan hasil simulasi atas skenario perubahan (stress test) (OJK, 2016).Target tingkat solvabilitas ini pada setiap perusahaan sebagai alat untuk mengirimkan isyarat yang nyata kepadapasarmengenai keamanan stakeholders. Setelahmenerimaisyaratmakapasarakanbereaksi terhadap keputusan investasi dan regulator akan memonitoring pada setiap perusahaan asuransi yang memiliki risk-based capital yang di bawah 120 persen.

\subsubsection{Risiko Kredit}

Teori Risiko pada dipandang sebagai sesuatu yang negatif, seperti bahaya,kehilangan, dan konsekuensi lainnya yang terjadi. Potensi kerugianyang menjadi ketidakpastian yang dipahami dan semestinya dikelola dengan baikyang tertuang dalam strategi perusahaan sehingga menjadi value addeddalam mendukung pencapaian tujuan organisasi (Lokobal, 2014, hal. 2).

Menurut SE-OJK No.24/SEOJK.05/2017 bagian II pada poin (1) huruf a, risiko kredit dapat dipahami sebagaipotensi terjadinya kehilangan atau penurunan nilai aset yang disebabkan oleh:(1) kegagalan debitur dan/atau pihak lain dalam memenuhi kewajiban kepada Perusahaan; (2). kegagalan/ketidakmampuan penanggung ulang (reasuradur) untuk memenuhi kewajibannya kepada Perusahaaan.Ketika mengelola risiko kredit, perusahaan asuransi terutama harus berupaya menghindari risiko konsentrasi (misalnya konsentrasi investasi dalam kategori investasi tertentu, tingkat rendah diversifikasi portofolio) dan berusaha keras untuk mencapai sebanyak mungkin diversifikasi dalam investasi mereka.Adanya risiko kredit adalah risiko kerugian finansial, terlepas dari realisasi jaminan agunan atau properti, yang dihasilkan dari kegagalan seorang debitur dalam memenuhi kewajiban kepada perusahaan (Sisay, 2017).Risiko kredit dapat menjadipotensipenurunan suatu aset ataskegagalan perusahaan dalam memenuhi kewajiban atau penanggung ulang (reasuradur) untuk memenuhi kewajibannya kepada perusahaaan. Kerugian finansial akan muncul jika salah satu pihak tidak mematuhi perjanjian polis dalam konteks perusahaan asuransi (Solomon, Muntean, \& Alecsandri, 2012).

\subsubsection{Risiko Solvabilitas}

Solvabilitas adalah kemampuan untuk memenuhi biaya tetap jangka panjang dan mencapai ekspansi dan pertumbuhan jangka panjangperusahaan.Rasio solvabilitas lebih dari dua puluh persen dianggap sehat secara finansial. Rasio solvabilitas yang tersedia berarti kelebihan nilai aset di atas nilai kewajiban asuransi dan kewajiban lain dari dana pemegang polis dan pemegang saham. Solvabilitas kategori asuransi sebagaimana dinyatakan melalui solvabilitas margin dan dengan demikian memberi kita gambaran tentang ukuran dan kondisi kecukupan modal perusahaan asuransi. Solvency margin adalah jumlah modal yang harus dipegang perusahaan asuransi untuk menutupi biaya yang mungkin terjadi karena terjadinya peristiwa yang tidak terduga (Nurfadila, Hidayat, \& Sulasmiyati, 2015).

\subsubsection{Kualitas Audit}

Kualitas audit dapat dipahami dengan memisahkan antara pengertian kualitas dan audit.Audit didefinisikan atas pemeriksaan secara objektif yang dilakukan oleh seorang akuntanatas informasi keuangan organisasi yang bertujuan dalam menentukan apakah laporan keuangan tersebut menyajikan secara wajar keadaan keuangan dan kinerja perusahaan (Tandiontong, 2016, hal. 159,67).Kantor akuntan dengan klasifikasiBig Fourdianggap 
memiliki kualitas jasa audit yang lebih baik dibandingkan dengan kantor akuntan publik dengan klasifikasi selain Big Four. Seorang auditor dituntut untuk memiliki independensi, kompetensi dan pertimbangan profesional dalam menilai keadaan entitas dan penilaian risiko perusahaan berdasarkan Generally Accepted Accounting Principles (GAAP) dalam bentuk opini atas laporan keuangan perusahaan yang dirilis oleh KAP.Banyak peneliti yang sepakat bahwa penggunaan audit yang berkualitas harus dilakukan oleh auditor yang kompeten dan independen dan menjadi kekuatan pemonitoran (monitoring strength) (Tandiontong, 2016). Penggunaan audit yang berkualitas dapat dilihat dari penunjukan KAP Big Four dan KAP selain Big Four. KAP diyakini akanmemberikanjasaatestasi maupun audityang lebih independen dalam mengungkapkan praktik-praktik manajemen laba yang diterapkan oleh perusahaan dengan tujuan tertentu.

\subsubsection{Kualitas Laba}

Kualitas laba merujuk pada suatu ukuran untuk mengkonfirmasi apakah laba yang diperoleh sama dengan yang direncanakan sebelumnya. Kemampuan laba merefleksikan laba perusahaan yang sebenarnya dalam memprediksi laba periode mendatang dengan mempertimbangkan persistensi dan stabilitas laba (Surifah, 2010). Kualitas laba (earnings quality) yang tinggi merepresentasikan fundamental laba perusahaan yang relevan ditujukan kepada para pengambil keputusan (Dechow, Ge, \& Schrand, 2010). Beberapa atribut yang digunakan untuk mengukur earnings quality meliputi persistensi (persistence), value relevance, kualitas akrual (accruals quality), prediktabilitas(predictability),conservatism, smoothness, timelinessserta pendekatan distribusi laba (Dechow, Ge, \& Schrand, 2010; Phillips, Pincus, \& Rego, 2003).

\subsection{Hasil Penelitian Terdahulu dan Hipotesis}

Risiko kredit menjadi dampak dari suatu kegagalan dalam memenuhi suatu kewajiban kepada pihak tertentu sesuai dengan kesepakatan perjanjian. Risiko kredit mencakup kegagalan pembayaran portofolio obligasi atas entitas asuransi. Likuiditas yang tinggi akan menghilangkan kebutuhan manajemen untuk meningkatkan kinerja operasional tahunannya pada perusahaan asuransi (Wani \& Dar, 2015).Risiko kredit juga timbul karena ketidakmampuan atau keengganan pihak peminjam untuk mengeksekusi sesuai dengan yang telah dikomitmenkan sebelumnya sehingga pengendalian risiko kredit dapat dikurangi pada tingkat minimum pinjaman yang macet atas kinerja melalui tingkat pengembalian aset / return on assets (ROA) (Olalekan, Olumide, \& Irom, 2018). Beberapa peneliti terdahulu menyatakan bahwa risiko kreditberpengaruh negatif signifikan terhadap profitabilitas bank dan perusahaan asuransi (Sisay, 2017; Olalekan, Olumide, \& Irom, 2018; Suryo, Rahayu, \& Nurbaiti, 2016).

Risiko solvabilitas mencerminkan perbedaanatas pengelolaan kekayaan dan kewajiban sebagai akibat dari risiko yang timbul. Rasio solvabilitas dengan tingkat lebih besar dari 20 persen menggambarkan kinerja keuangan dinyatakan perusahaan pada industri asuransi properti mengungkapkan bahwa kekuatan perusahaan jauh akan lebih besar finansial perusahaan-perusahaan ketika menduduki rangking atas premi asuransi (Wani \& Dar, 2015). Ketidakmampuan lembaga keuangan saat memenuhi kewajiban keuangan jangka pendek, jangka menengah dan jangka panjangnya sehingga terjadi penghentian aktivitas atau likuidasi (Sisay, 2017). Risiko solvabilitas memiliki pengaruh yang signifikan terhadap kinerja keuangan melalui profitabilitas ROA dan ROE (Wani \& Dar, 2015; Ullah, Faisal, \& Zuhra, 2016; Bogar, 
2016; Sisay, 2017). Oleh karena itu, hipotesis alternatif ke-1 dan ke-2 dinyatakan sebagai berikut:

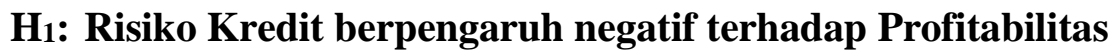 H$_{2}$ : Risiko Solvabilitas berpengaruh negatif terhadap Profitabilitas}

Profitabilitas sebagai outcome kinerja perusahaan atas investasi diakhiri dengan net income sebagai bottom-line yang menjadibahan bagi stockholders'sebelum menyelenggarakan Rapat Umum Pemegang Saham (RUPS) untuk mengetahui tingkat pengembalian investasi dan kesehatan perusahaan. Penetapan untuk memilih KAP Big Four maupun selain Big Four melibatkan seperangkat struktur pengendalian eksternal yang tertuang dalam corporate governance. Audit eksternal dalam menjalankan perannya secara efektif mempunyai 2 (dua) dimensi yaitu: standar umum dan standar pelaporan yang diukur dengan beberapa indikator yang mencerminkan kualitas audit (Merawati \& Hatta, 2014). Temuan penelitian yang menguji kualitas audit Big-4 terhadap profitabilitas perusahaan belum banyak dilakukan oleh penelitian terdahulu. Pentingnya pengukuran kualitas audit ini untuk menguji profitabilitas perusahaan dirumuskan ke dalam hipotesis alternatif ke-3 berikut ini:

\section{H3: $\quad$ Kualitas Audit berpengaruh positif terhadap Profitabilitas}

Profitabilitas untuk mengukur tingkat kualitas laba juga dipengaruhi oleh profitabilitas perusahaan dengan pendekatan income smoothing (perataan laba) secara positif (Lathifah, Hidayati, \& Malikah, 2018). Sementara pengukuran profitabilitas dengan pengembalian investasi masih menghasilkan nilai di bawah batas minimal atau dengan kata lain rasio profitabilitas ini memiliki hubungan yang sangat lemah yaitu 15 persen (Nurfadila, Hidayat, \& Sulasmiyati, 2015). Temuan penelitian yang menguji kualitas laba dengan faktor profitabilitas dengan proksi ROA memiliki pengaruh negatif dan signifikan (Laoli \& Herawaty, 2019). Pentingnya rasio profitabilitas ini untuk menguji kualitas laba dirumuskan ke dalam hipotesis alternatif ke- berikut ini:

\section{H4: $\quad$ Profitabilitas berpengaruh positif terhadap Kualitas Laba}

Risiko keuangan yang diproksikan dengan leverage juga tidak mengkonfirmasi temuannya terhadap kualitas laba dengan pendekatan perataan laba (Lathifah, Hidayati, \& Malikah, 2018). Sementara variabel Risk Based Capital (RBC) berpengaruh terhadap kinerja keuangan (Sumartono \& Harianto, 2018). Oleh karena itu, hipotesis alternatif ke-5 dan ke6dinyatakan sebagai berikut:

\section{H5: Risiko Kredit berpengaruh negatif terhadap Kualitas Laba \\ H6: Risiko Solvabilitas berpengaruh negatif terhadap Kualitas Laba}

Auditor dapat meningkatkan kepercayaan stockholders' menggunakan standar profesional kerja yang bertujuan mengurangi risiko litigasi serta menjaga reputasi dengan memberikan jaminan atas misstatement dan kecurangan dalam laporan keuangan auditee. Pembatasan praktik kualitas laba ini diharapkan dapat meningkatkan kepercayaan pemegang saham dan sinyal baik bagi investor dalam pengambilan keputusan investasi. Kualitas audit mempunyai peran terhadap kualitas laba dengan arah positif (Aryengki, Satriawan, \& Rofika, 2016), sementara dalam mendeteksi praktik manajemen laba yang menggunakan salah satu teknik pengukuran kualitas laba tidak menunjukkan pengaruh yang signifikan menggunakan faktor ukuran KAP dengan prokosi The Big-4 dan lainnya (Ulina, Mulyadi, \& Tjahjono, 2018). Temuan penelitian di atas yang mengkonfirmasi dan tidak mengkonfirmasi faktor kualitas audit 
dengan pendekatan KAP Big-Four dan selain Big-Four, melatarbelakangi penggunaan kualitas audit yang difungsikan terhadap kualitas laba dengan rumusan hipotesis berikut ini:

\section{H7: $\quad$ Kualitas Audit berpengaruh terhadap Kualitas Laba}

Berikut ini adalah model yang dirumuskan pada penelitian ini:

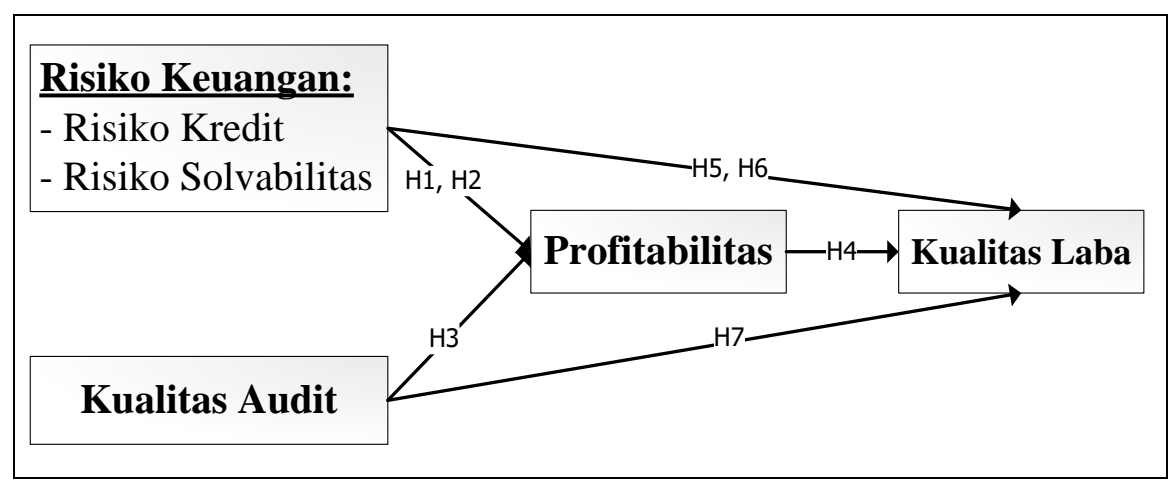

\section{Gambar 3. Model Penelitian}

\section{METODE PENELITIAN \\ 3.1.Metode Penelitian}

Metode penelitian ini menggunakan pendekatankuantitatifdengan mencoba melakukan pengukuran yang akurat terhadap perilaku, pengetahuan, opini, atau sikap (Indrawati, 2015, hal. 184). Penelitian ini menggunakan serangkaian observasi atau pengukuran hasilnya menggunakan data sekunder yang diperoleh dari laporan tahunan dan laporan keuangan perusahaan yang terdaftardi BEI.

\subsection{Populasi dan Sampel Penelitian}

Populasi penelitian ini adalah perusahaan sektor keuangan sub sektor asuransi umum yang terdaftar di BEI (Bursa Efek Indonesia) tahun 2014-2018. Prosedur sampling menggunakan metode purposive, yaitu dengan pertimbangan tertentu (Sugiyono, 2018, hal. 126). Penetapan sampel penelitian inidengan pertimbangan kriteria: (a) Perusahaanmerupakan kategori asuransi umum; (b) Perusahaanlisting di BEI berturut-turut selama periode pengamatan; dan (c) Perusahaan yang menggunakan mata uang rupiah (IDR) sebagai mata uang pelaporan dikonversikan ke dalam Kurs Tengah Bank Indonesia (BI).

Sampel awal perusahaan sub sektor asuransi yang terdaftar di BEI tahun 2018 sebanyak 15 (lima belas) perusahaan dengan mengeliminasi: (a)2perusahaan pada kategori asuransi jiwa, yaitu PT Asuransi Jiwa Syari'ah Jasa Mitra Abadi, Tbk. dan Asuransi Jiwa Sinarmas MSIG, Tbk.; (b) 1 perusahaan reasuransi, yaitu PT Maskapai Reasuransi Indonesia, Tbk.; dan (c) perusahaan yanglistingsejak periode tahun 2017-2018yaitu PT Malacca Trust Wuwungan Insurance, Tbk. dan PT Asuransi Tugu Pratama Indonesia, Tbk. Akhirnya, hasil seleksi sampel menghasilkan 10 (sepuluh) perusahaan sub sektor asuransi umumpada Tabel 1. 
Tabel 1. Hasil Seleksi Sampel

\begin{tabular}{ccc}
\hline Kode Saham & Nama Perusahaan & Tanggal IPO \\
\hline ABDA & Asuransi Bina Dana, Tbk. & 06-Jul-1989 \\
AHAP & Asuransi Harta Aman Pratama, & 14-Sep-1990 \\
AMAG & Tbk. & 23-Des-2005 \\
ASBI & Asuransi Multi Artha Guna, Tbk. & 29-Nov-1989 \\
ASDM & Asuransi Bintang, Tbk. & 15-Des-1989 \\
ASJT & Asuransi Dayin Mitra, Tbk. & 29-Des-2003 \\
ASMI & Asuransi Jasa Tania, Tbk. & 16-Jan-2014 \\
ASRM & Asuransi Kresna Mitra, Tbk. & 19-Mar-1990 \\
LPGI & Asuransi Ramayana, Tbk. & 22-Jul-1997 \\
VINS & Lippo General Insurance, Tbk. & 28-Sep-2015 \\
\multicolumn{3}{c}{ Victoria Insurance, Tbk. } \\
\hline $\mathbf{1 0}$ & Perusahaan & Jumlah \\
\hline & (Sumber: Data BEI, 2019)
\end{tabular}

Total pengamatan yang dilakukan untuk tahun penelitan yaitu 50 data observasi.

\subsection{Definisi dan Operasionalisasi Variabel}

Variabel Risiko Kredit (X1)didefinisikan sebagai potensi risiko akibat adanya penurunan nilaiatau kehilangan aset ataskegagalan debitur dan/atau pihak lain dalam memenuhi kewajiban kepada perusahaan serta kegagalan/ketidakmampuan penanggung ulang (reasuradur) untuk memenuhi kewajibannya kepada perusahaaan. Pengukuran risiko kredit dikalkulasikan dengan rumus berikut ini:

$\mathrm{CR}=\frac{\text { Premium Debtor }+ \text { Due from Reinsurer's }+ \text { Other Receivable }}{\mathrm{TA}}$

Keterangan:

$\mathrm{CR}=$ Credit Risk

$\mathrm{TA}=$ Net Assets

(Sisay, 2017, hal. 57)

Variabel Risiko Solvabilitas (X2)didefinisikan sebagai potensi risiko yang berdampakatasdeviasi dalam pengelolaan kekayaan. Tingkat solvabilitas mengabaikan adanya jumlah kekayaan yang lebih besar dibandingkan dengan jumlah kewajiban dan modal yang disetor minimum (MMBR). Pengukuran risiko profitabilitas menggunakan proksi risk-based capital (RBC) yang merupakan satu parameter untuk mengukur kinerja kesehatan dan keamanan keuangan perusahaan.

Variabel Kualitas Audit (X3) menggunakan pengukuran dummy variable, yaitu pengkodean "1" dan "0" berdasarkan kategori Kantor AuditorBig Four dan selain Big Four. Jika perusahaan diaudit auditor Big Four diberi kode"1"dan apabila perusahaan diaudit auditor selain ketagori Big Four diberi kode "0" (Oh, Park, \& Hong, 2016).

Variabel Profitabilitas Perusahaan (Y1) didefinisikan sebagai efektivitas manajemen dalam konteks pengelolaan suatu investasi (Kasmir, 2016, hal. 201). Pengukuran profitabilitas 
perusahaan menggunakan pendekatan return on investment (ROI) yang dikalkulasikan dengan rumus berikut:

\begin{tabular}{|c|} 
Investment Income \\
Average Fair Value of Investments
\end{tabular}

Keterangan:

Average $F V$ of Investments=Beginning $F V+$ Ending $F V / 2$

(Subramanyam, 2014, hal. 321)

Variabel Kualitas Laba (Y2) merupakankualitas (quality) yang tinggi dan secarafaithfullyyang menggambarkan fundamental labaperusahaan bagiparastakeholders' (Dechow, Ge, \& Schrand, 2010).Pengukuran kualitas laba menggunakan pendekatanearnings allocationyang dikalkulasikan dengan rumus berikut:

$\Delta \mathrm{E}=\mathrm{E}_{\mathrm{it}}-\mathrm{E}_{\mathrm{it}-1}$
MVEit-1

\section{Keterangan:}

$\Delta \mathrm{E}=$ Distribusi laba, jika nilai $\mathrm{E}=$ positif atau 0 maka perusahaan menghindari penurunan laba. Jika nilai $\mathrm{E}=$ negatif maka perusahaan menghindari pelaporan kerugian.

$\mathrm{E}_{\mathrm{it}} \quad=$ laba perusahaan i pada tahun $\mathrm{t}$

$\mathrm{E}_{\mathrm{it}-1} \quad=$ laba perusahaan i pada tahun $\mathrm{t}-1$

$\mathrm{MVE}_{\mathrm{it}-1}=$ Market value of equity perusahaan i pada tahun $\mathrm{t}-1$

(Phillips, Pincus, \& Rego, 2003; Sumomba \& Hutomo, 2012)

\subsection{Teknik Analisis Data}

Teknik analisis data menggunakan analisis jalur (path analysis). Analisis jalur merupakan pengembangan model analisis regresi linear berganda yang telah dirumuskan sebelumnya berdasarkan teori. Hubungan kausalitas antar variabel penelitian yang dirumuskan dengan suatu model berdasarkan landasan teoritis yang bertujuan untuk menentukan pola hubungan tiga atau lebih variabel dan tidak dapat digunakan untuk mengkonfirmasi atau menolak hipotesis imajiner (Ghozali, Aplikasi Analisis Multivariate Dengan Program: IBM SPSS 23, 2017, hal. 237). Persamaan regresi yang dirumuskan pada penelitian ini yaitu:

$$
\begin{array}{ll}
\mathrm{Y} 1=\alpha+\beta 1 \mathrm{X} 1+\beta 2 \mathrm{X} 2+\beta 3 \mathrm{X} 3+\mathrm{e} 1 & (1) \\
\mathrm{Y} 2=\alpha+\beta 4 \mathrm{Y} 1+\beta 5 \mathrm{X} 1+\beta 6 \mathrm{X} 2+ & \beta 7 \mathrm{X} 3+\mathrm{e} 2
\end{array}
$$

Keterangan:

$$
\begin{array}{ll}
\hline \text { Y1 } & \text { : Profitabilitas Perusahaan } \\
\text { Y2 } & \text { : Kualitas Laba } \\
\alpha & =\text { Konstanta } \\
\beta_{1} & =\text { Koefisien jalur X1 dengan Y1 } \\
\beta_{2} & =\text { Koefisien jalur X2 dengan Y1 } \\
\beta_{3} & =\text { Koefisien jalur X3 dengan Y1 } \\
\beta_{4} & =\text { Koefisien jalur Y1 dengan Y2 } \\
\beta_{5} & =\text { Koefisien jalur X1 dengan Y2 } \\
\beta_{6} & =\text { Koefisien jalur X2 dengan Y2 }
\end{array}
$$


$\begin{array}{ll}\beta_{7} & =\text { Koefisien jalur X3 dengan Y2 } \\ \text { è } & =\text { Faktor Pengganggu (error) }\end{array}$

Uji asumsi klasik sebagai langkah awaluntuk memprediksi sampel yang diteliti dengan kriteria BLUE (best linier unbias estimator) terbebas dari permasalahan normalitas, multikolinearitas heteroskedastisitas serta gangguan autokorelasi. Setelah lolos dari uji asumsi klasik, maka dapat dilanjutkan ke dalam uji hipotesis spesifikasi model yang digunakan apakah sudah benar atau tidak yang digunakansebagai dasar model apakah berbentuk linier, kuadratik, kubik, inverse,logarithmic, power, S, compound, growth dan eksponensial dengan kriteria jikanilai $\mathrm{F}_{\text {-Stats }}>\mathrm{F}$-Table atau nilai signifikansi $\alpha<0,05$, maka model dinyatakan linear (Ha diterima) (Ghozali, Aplikasi Analisis Multivariate Dengan Program: IBM SPSS 23, 2017, hal. 159). Selanjutnya uji koefisien determinasi total $\left(\mathrm{Rm}^{2}\right)$ dilakukan untuk mengukur kekuatan pengaruh yang terjadi antara variabel independen terhadap variabel dependen dalam suatu model penelitian (Ghozali, Aplikasi Analisis Multivariate Dengan Program: IBM SPSS 23, 2017, hal. 239). Uji analisis jalur (path analysis) yang dimaksudkan untuk memprediksi sejauhmana kontribusi perubahan yang terjadi pada masing variabel independen terhadap besarnya variabel dependen baik secara langsung maupun melalui variabel intevening dalam pengujian hipotesis. Pengujian hipotesis dengan multiple mediation model dapat dilakukan dengan prosedur yangdikembangkan oleh Sobel (1982) dan dikenal dengan uji Sobel (Sobel test) dan Bootstrapping dalam bentuk script makroSPSS (Ghozali, Aplikasi Analisis Multivariate Dengan Program: IBM SPSS 23, 2017, hal. 243). Sobel testbertujuan untuk menguji kekuatan pengaruh tidak langsung variabel independen $(\mathrm{X})$ kepada variabel $(\mathrm{Y})$ melalui variabel intervening (M). Pengaruh tidak langsung Variabel $\mathrm{X}$ ke Y melalui $\mathrm{M}$ dapat dihitung dengan cara mengalikan jalur (path) $\mathrm{X} \rightarrow \mathrm{M}$ (a) dengan jalur (path) $\mathrm{M} \rightarrow \mathrm{Y}$ (b) atau disingkat dengan "ab". Koefisien $a b=(c-c$ '), dimana "c" adalah pengaruh $\mathrm{X}$ terhadap $\mathrm{Y}$ setelah mengontrol M (Ghozali, Aplikasi Analisis Multivariate Dengan Program: IBM SPSS 23, 2017, hal. 236) [17].Keseluruhan data diolah dengan software IBM SPSS Versi 24.00.

\section{HASIL DAN PEMBAHASAN}

\subsection{Analisis Statistik Deskriptif}

Tabel 2. Hasil Deskriptif Statistik

Descriptive Statistics

\begin{tabular}{|l|l|l|l|l|l|}
\hline & N & Min & Max & Mean & $\begin{array}{l}\text { Std. } \\
\text { Deviation }\end{array}$ \\
\hline X1 & 50 & 0,0814 & 0,6136 & 0,229442 & 0,1189992 \\
X2 & 50 & 1,3087 & 10,6419 & 3,02231 & 2,1730141 \\
X3 & 50 & 0 & 1 & 0,28 & 0,454 \\
Y1 & 50 & $-0,2130$ & 5,0500 & 0,452556 & 1,1272085 \\
Y2 & 50 & 0 & 3,2998 & $-0,002287$ & 0,6412138 \\
Valid N & 50 & & & & \\
(listwise) & & & & & \\
\hline
\end{tabular}

(Sumber: Output SPSS 23,00, 2020) 
Risiko Kredit (X1) menghasilkansebaran deskriptif yang berkisar antara skor 0,0814 dan 0,6136. Nilai rata-rata credit risk (CR) diperoleh sebesar 0,229442 dengan standar deviasi sebesar 0,1189992. Artinya, 50data observasi pada perusahaan sub sektor asuransi umum yang terdaftar di BEI tahun 2014-2018 memilikivariasi data sampel yang cukup besar (perbandingan nilai rata-rata dengan standar deviasi lebih dari 30\%).

Risiko Solvabilitas (X2) menghasilkansebaran deskriptif yang berkisar antara skor 1,3087 dan 10,64191. Nilai rata-rata risk-based capital (RBC) diperoleh sebesar3,02231 dengan standar deviasi sebesar 2,1730141. Artinya, 50data observasipada perusahaan sub sektor asuransi umum yang terdaftar di BEI tahun 2014-2018 memilikivariasi data sampel yang cukup besar (perbandingan nilai rata-rata dengan standar deviasi lebih dari 30\%).

Kualitas Audit (X3) menghasilkansebaran deskriptif yang berkisar antara skor 0 dan 1. Nilai rata-rata diperoleh sebesar 0,28 dengan standar deviasi sebesar 0,454. Nilai 0,28 persen artinya perusahaan diaudit oleh KAP dengan kategori Big-Four.50data observasipada perusahaan sub sektor asuransi umum yang terdaftar di BEI tahun 2014-2018 memilikivariasi data sampel yang cukup besar (perbandingan nilai rata-rata dengan standar deviasi lebih dari $30 \%)$.

\subsection{Uji Asumsi Klasik}

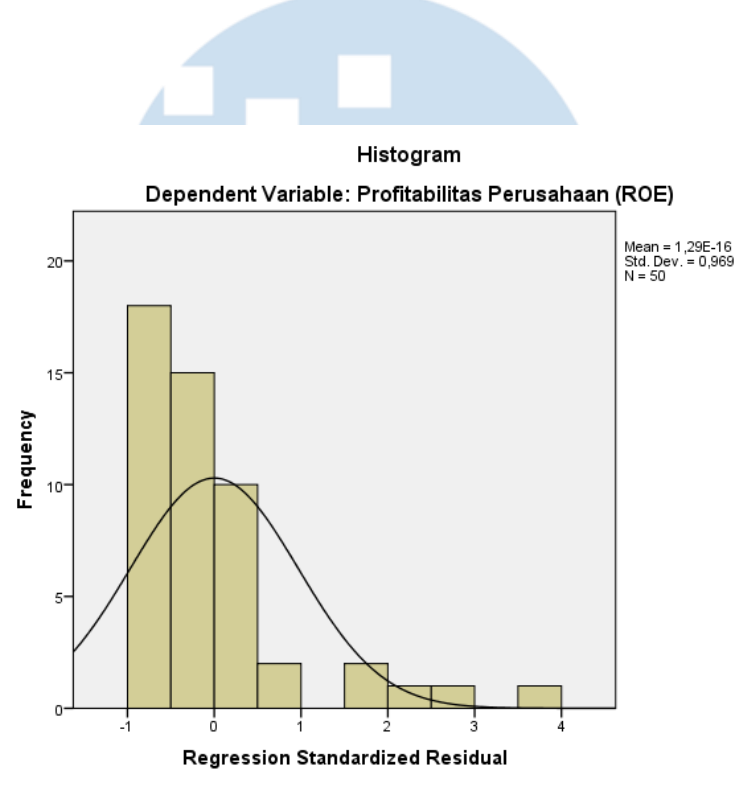

Gambar 4.Histogram Uji Normalitas ... (1) 


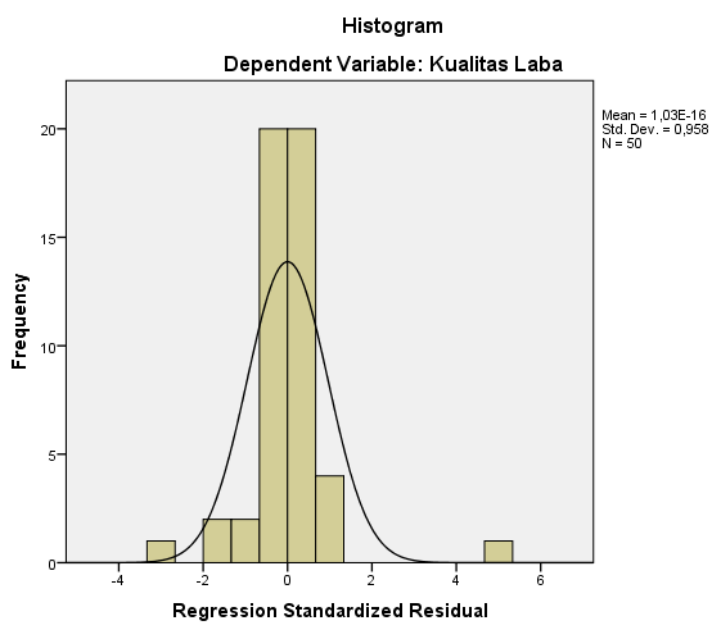

\section{Gambar 5.Histogram Uji Normalitas ... (2)}

Grafik histogram pada model regresi 1 dan 2 menghasilkan nilai residual data menunjukkan kurva normal yang membentuk lonceng sempurna.

\begin{tabular}{lll}
\multicolumn{2}{l}{ Tabel 3. Hasil Uji Multikolinearitas } \\
\hline $\begin{array}{l}\text { Variabel } \\
\text { Independen }\end{array}$ & $\begin{array}{l}\text { Nilai } \\
\text { Tolerance }\end{array}$ & $\begin{array}{l}\text { Nilai } \\
\text { VIF }\end{array}$ \\
\hline \multicolumn{2}{l}{ Model Regresi 1} \\
\hline X1 & 0,841 & 1,189 \\
X2 & 0,801 & 1,248 \\
X3 & 0,932 & 1,073 \\
\hline \multicolumn{3}{l}{ Model Regresi 2 } \\
\hline X1 & 0,774 & 1,291 \\
X2 & 0,684 & 1,463 \\
X3 & 0,844 & 1,185 \\
Y1 & 0,806 & 1,240 \\
\hline \multicolumn{3}{l}{ (Sumber: Data diolah SPSS 23,00,2020) }
\end{tabular}

Hasil uji multikolinearitas pada model regresi 1 dan 2 menghasilkan nilai toleranceyang lebih besar dari 0,1 dan nilai VIF lebih kecil dari skor 10 sehingga dapat disimpulkan bahwa kedua model regresi terbebas dari permasalahan multikolinearitas.

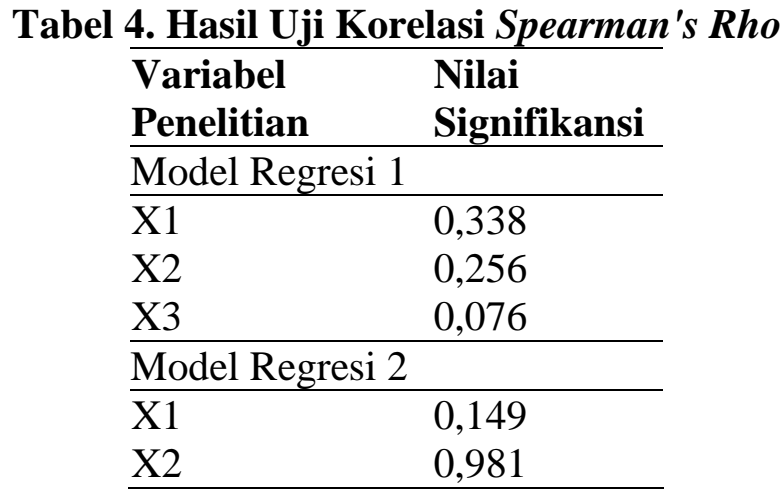




\begin{tabular}{ll}
\hline $\mathrm{X} 3$ & 0,405 \\
$\mathrm{Y} 1$ & 0,288 \\
\hline
\end{tabular}

(Sumber: Data diolah SPSS 23,00, 2020)

Hasil uji korelasi Spearman's Rhopada model regresi 1 dan 2 dalam uji heteroskedastisitas menunjukkan bahwa seluruh variabelmemiliki nilai signifikansi lebih besar dari 0,05 sehingga dapat disimpulkan bahwa kedua model regresi terbebas dari permasalahan heteroskedastisitas.

Tabel 5. Hasil Uji Autokorelasi

\begin{tabular}{lllll}
\hline & $\mathbf{d U}$ & $\mathbf{d L}$ & 4-dU & $\mathbf{d W}$ \\
\hline Model 1 & 1,6692 & 1,3989 & 2,3308 & 0,605 \\
Model 2 & 1,7203 & 1,3535 & 2,2797 & 2,308 \\
\hline \multicolumn{5}{c}{ (Sumber: Data diolah SPSS $23,00,2020)$}
\end{tabular}

Hasil uji autokorelasi menghasilkan nilai durbin watsonpada kedua model regresi masing-masing sebesar 0,605 dan 2,308. Ketentuan uji autokorelasi mensyaratkan bahwa model regresi berada di antara nilai $\mathrm{du} \leq \mathrm{dw} \leq(4-\mathrm{du})$. Nilai $\mathrm{dW}$ pada model regresi 1 berada pada $0<\mathrm{d}<\mathrm{dL}$ yang artinya tidak adaautokorelasi positif, hal ini masih memiliki permasalahan autokorelasi sementara pada model regresi 2 berada pada $4-\mathrm{du} \leq \mathrm{d} \leq 4-\mathrm{dl}$ yang artinya tidak adakorelasi negatif.Untuk mengatasi permasalahan autokorelasi dalam penelitian ini maka selanjutnya dapat kembali melakukan transformasi cochrane orcutt agar mendapatkan nilai koefisien autokorelasiRho $(\rho)$ pada masing-masing model regresi sebesar sebesar 0,689 dan 0,154 yang kemudian ditranformasi ke masing-masing variabel baru.

Tabel 6. Hasil Uji Autokorelasi

(setelah transformasi data)

\begin{tabular}{lllll}
\hline & dU & dL & 4-dU & dW \\
\hline Model 1 & 1,6692 & 1,3989 & 2,3308 & 1,667 \\
Model 2 & 1,7203 & 1,3535 & 2,2797 & 2,068 \\
\hline
\end{tabular}

(Sumber: Data diolah SPSS 23,00, 2020)

Hasil uji autokorelasi pada model regresi 1 menghasilkan nilai durbin watsonsebesar 1,630, hasil ini telah mendekati nilai di antara nilai $\mathrm{du} \leq \mathrm{dw} \leq(4-\mathrm{du})$ sedangkan pada model regresi 2 menghasilkan nilai durbin watsonsebesar2,068 yang disyaratkan dalam ketentuan uji autokorelasi yaitu model regresi tidak menunjukkan adanya autokorelasi positif atau negatif.

\subsection{Uji Hipotesis}

Tabel 7. Rangkuman Hasil Uji Koefisien Determinasi Total $\left(\mathbf{R m}^{2}\right)$

\begin{tabular}{llll}
\hline & $\begin{array}{l}\text { Nilai } \\
\text { R }\end{array}$ & $\begin{array}{l}\text { Nilai } \\
\text { Adjusted } \\
\text { R-Square }\end{array}$ & $\begin{array}{l}\text { S.E. of } \\
\text { the } \\
\text { Estimate }\end{array}$ \\
\hline $\begin{array}{l}\text { Model } \\
\text { Regresi 1 } \\
\text { Model } \\
\text { Regresi2 }\end{array}$ & 0,194 & 0,141 & 1,0445666 \\
\hline
\end{tabular}

(Sumber: Output SPSS 23,00, 2020) 
Hasil Perhitungan Standar error of estimate dari Model Regresi 1 dan 2:

$$
\begin{aligned}
\text { Pe1 } & =\sqrt{1-R^{2}} \\
& =\sqrt{1-(0,194)} \\
& =\sqrt{0,806} \\
& =0,8977 \\
\operatorname{Pe} 2 & =\sqrt{1-R^{2}} \\
& =\sqrt{1-(0,021)} \\
& =\sqrt{0,979} \\
& =0,9894
\end{aligned}
$$

\begin{tabular}{|c|c|c|c|}
\hline $\begin{array}{l}\text { Jalur } \\
\text { (Path) }\end{array}$ & $\begin{array}{l}\text { Pengaruh } \\
\text { antar } \\
\text { Variabel }\end{array}$ & $\begin{array}{l}\text { Nilai } \\
\text { Standard } \\
\text { ized Beta } \\
(\beta)\end{array}$ & $\begin{array}{l}\text { Nilai } \\
\text { Signifikan } \\
\text { si }\end{array}$ \\
\hline $\mathrm{p} 1$ & $\begin{array}{l}\mathrm{H}_{1}: \\
\mathrm{X} 1 \rightarrow \mathrm{Y} 1\end{array}$ & $-2,727$ & 0,052 \\
\hline p2 & $\begin{array}{l}\mathrm{H}_{2}: \\
\mathrm{X} 2 \rightarrow \mathrm{Y} 1\end{array}$ & $-0,216$ & 0,007 \\
\hline p3 & $\begin{array}{l}\mathrm{H}_{3}: \\
\mathrm{X} 3 \rightarrow \mathrm{Y} 1\end{array}$ & $-0,750$ & 0,033 \\
\hline p4 & $\begin{array}{l}\mathrm{H}_{4}: \\
\mathrm{Y} 1 \rightarrow \mathrm{Y} 2\end{array}$ & 0,000 & 0,999 \\
\hline p5 & $\begin{array}{l}\mathrm{H}_{5}: \\
\mathrm{X} 1 \rightarrow \mathrm{Y} 2\end{array}$ & $-0,820$ & 0,369 \\
\hline p6 & $\begin{array}{l}\mathrm{H}_{6}: \\
\mathrm{X} 2 \rightarrow \mathrm{Y} 2\end{array}$ & $-0,025$ & 0,632 \\
\hline p7 & $\begin{array}{l}\mathrm{H}_{7}: \\
\mathrm{X} 3 \rightarrow \mathrm{Y} 2\end{array}$ & $-0,066$ & 0,771 \\
\hline
\end{tabular}

Berdasarkan total keragaman data yang dijelaskan oleh model regresi 1 dan 2 dapat dihitung dengan rumus:

$$
\begin{aligned}
\mathrm{Rm}^{2} & =1-\mathrm{p}^{2} \mathrm{e}_{1} \mathrm{p}^{2} \mathrm{e}_{2} \\
& =1-(0,8977)^{2} \times(0,9894)^{2} \\
& =1-(0,8059 \times 0,9789) \\
& =1-0,7889 \\
& =0,2111
\end{aligned}
$$

Tabel 8. Hasil Uji Analisis Jalur (path analysis) - Pengaruh Langsung

Hasil uji path analysis hanya 2 (dua) yang memiliki probabilitas signifikansi yang lebih kecil dari $(<)$ 0,05 yaitu $\mathrm{p} 2(\mathrm{X} 2 \rightarrow \mathrm{Y} 1)$ dan $\mathrm{p} 3(\mathrm{X} 3 \rightarrow \mathrm{Y} 1)$ sehingga menerima $\mathrm{H}_{2}$ dan $\mathrm{H}_{3}$, sisanya p1, p4, p5, p6 dan p7 memiliki probabilitas signifikansi yang lebih besar dari (>) 0,05 sehingga masing-masing menerima $\mathrm{H}_{0}$. Hasil pengujian ini menunjukkan bahwa hanya risiko solvabilitas dan kualitas audit yang terbukti berpengaruh negatif dan signifikan terhadap profitabilitas 
perusahaan.Sementara, hasil dari pengujian hipotesis melalui analisis jalur (path analysis) pengaruh tidak langsung dijelaskan secara rinci sebagai berikut:

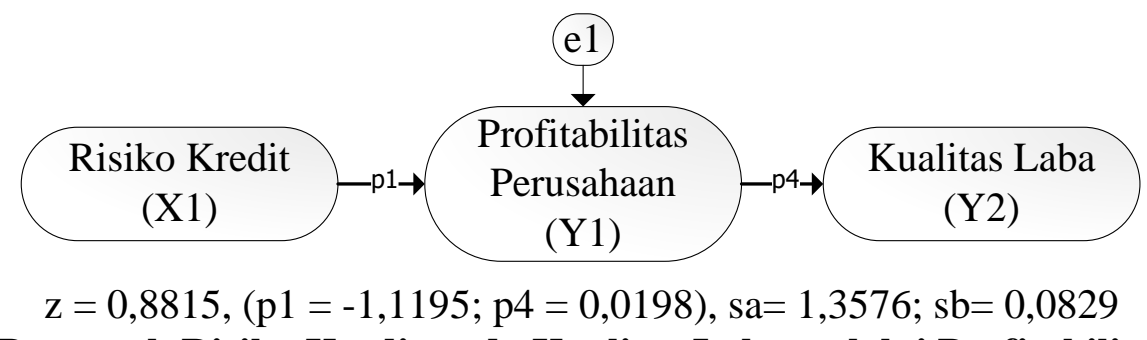

Gambar 6. Pengaruh Risiko Kredit pada Kualitas Laba melalui Profitabilitas Perusahaan

Hasil sobel test pada bagian indirect effect terlihat pengaruh tidak langsung Risiko Kredit terhadap Kualitas Laba melalui Profitabilitas Perusahaan sebesar-0,6352 yang merupakan hasil perkalian koefisien antara $b(M X)$ atau jalur p1 dengan $b(Y M . X)$. Nilai koefisien mediasi -0,0221 berada pada tingkat signifikansi 0,8815 yang lebih besar dari 0,05. Nilai standard error adalah 0,1484 sehingga nilai t hitung menjadi:

$\begin{aligned} \mathrm{t} & =\frac{-0,0221}{0,1484} \\ \mathrm{t} & =-0,1489\end{aligned}$

Nilai t hitung ini adalah lebih kecil dari t tabel dengan signifikansi 5\% yaitu sebesar 1,96 sehingga menolak $\mathrm{H}_{8}$. Variabel Profitabilitas Perusahaan tidak memediasi pengaruhRisiko KreditterhadapKualitas Laba.

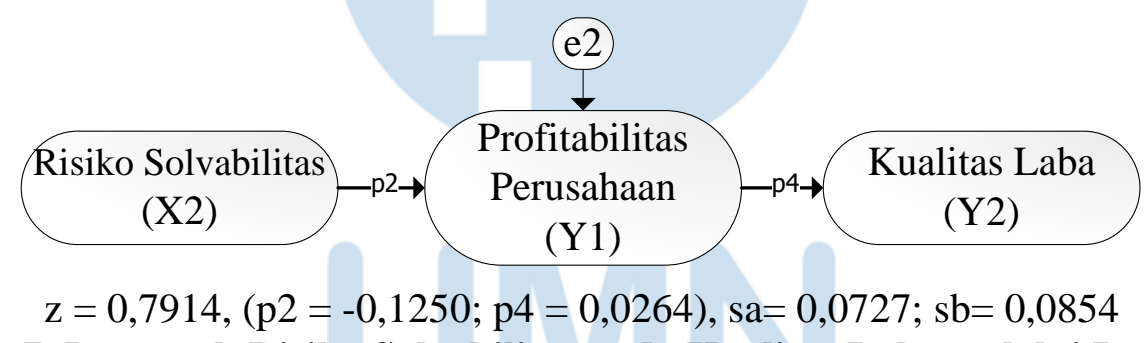

\section{Gambar 7. Pengaruh Risiko Solvabilitas pada Kualitas Laba melalui Profitabilitas Perusahaan}

Hasil sobel test pada bagian indirect effect terlihat pengaruh tidak langsung Risiko Solvabilitas terhadap Kualitas Laba melalui Profitabilitas Perusahaan sebesar-0,0054 yang merupakan hasil perkalian koefisien antara $b(M X)$ atau jalur p2 dengan b(YM.X). Nilai koefisien mediasi -0,0033 berada pada tingkat signifikansi 0,7914 yang lebih besar dari 0,05. Nilai standard error adalah 0,0125 sehingga nilai t hitung menjadi:

$$
\begin{aligned}
\mathrm{t} & =\frac{-0,0033}{0,0125} \\
\mathrm{t} & =-0,264
\end{aligned}
$$

Nilai t hitung ini adalah lebih kecil dari t tabel dengan signifikansi 5\% yaitu sebesar 1,96 sehingga menolak $\mathrm{H}_{9}$. Variabel Profitabilitas Perusahaan tidak memediasi pengaruhRisiko Solvabilitas terhadapKualitas Laba. 


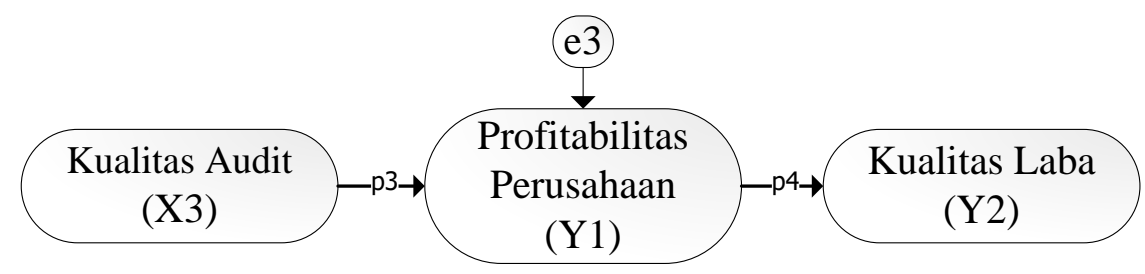

$\mathrm{z}=0,8056,(\mathrm{p} 3=-0,4902 ; \mathrm{p} 4=0,0260), \mathrm{sa}=0,3517 ; \mathrm{sb}=0,0845$

\section{Gambar 8. Pengaruh Kualitas Audit pada Kualitas Laba melalui Profitabilitas Perusahaan}

Hasil sobel test pada bagian indirect effect terlihat pengaruh tidak langsung Kualitas Audit terhadap Kualitas Laba melalui Profitabilitas Perusahaan sebesar-0,0304 yang merupakan hasil perkalian koefisien antara $b(M X)$ atau jalur p3 dengan $b(Y M . X)$. Nilai koefisien mediasi $-0,0128$ berada pada tingkat signifikansi 0,8056 yang lebih besar dari 0,05. Nilai standard error adalah 0,0518 sehingga nilai t hitung menjadi:

$$
\begin{aligned}
\mathrm{t} & =\frac{-0,0128}{0,0518} \\
\mathrm{t} & =-0,2471
\end{aligned}
$$

Nilai t hitung ini adalah lebih kecil dari t tabel dengan signifikansi 5\% yaitu sebesar 1,96 sehingga menolak $\mathrm{H}_{10}$. Variabel Profitabilitas Perusahaan tidak memediasi pengaruhKualitas Audit terhadapKualitas Laba.

\section{Tabel 9. Rangkuman Hasil Uji-F}

\begin{tabular}{lllll}
\hline Model & df1 & df2 & $\begin{array}{l}\text { Nilai F- } \\
\text { Hitung }\end{array}$ & $\begin{array}{l}\text { Probabilitas } \\
\text { Signifikansi }\end{array}$ \\
\hline 1 & 3 & 46 & 3,687 & 0,018 \\
2 & 4 & 45 & 0,236 & 0,917 \\
\hline & & & & \\
\hline
\end{tabular}

Nilai f-hitung pada model regresi 1 (sebelum moderasi) adalah sebesar 3,687 dengan nilai probabilitas 0,018 sehingga menolak $\mathrm{H}_{0}$, sementara nilai f-hitung pada model regresi 2 (setelah moderasi) adalah sebesar 0,236 dengan nilai probabilitas sebesar 0,917 sehingga menerima $\mathrm{H}_{0}$. Artinya Variabel Risiko Keuangan yang terdiri dari Risiko Kredit dan Risiko Solvabilitas serta Variabel Kualitas Audit berpengaruh secara simultan sebelum dimediasi oleh Profitabilitas Perusahaan terhadap Kualitas Laba sementara setelah dimediasi oleh Profitabilitas Perusahaan tidak berpengaruh secara simultan terhadap Kualitas Laba. 


\section{PEMBAHASAN}

Berdasarkan hasil uji hipotesis di atas, maka pembahasan hasil penelitian yang dimaksud dikaitkan dengan teori maupun hasil dari penelitian terdahulu adalah sebagai berikut: a. Hipotesis alternatif ke-1 menyatakan bahwa Risiko Kreditberpengaruh negatif terhadap Profitabilitas Perusahaan memiliki koefisien regresi $\beta 1$ sebesar -2,727 dengan probabilitas signifikansi sebesar 0,052. Hasil pengujian hipotesis menunjukkan bahwa Risiko Kredit yang diukur berdasarkan credit risk terbukti tidak berpengaruh signifikan terhadap Profitabilitas Perusahaan. Risiko kredit juga timbul karena ketidakmampuan debitur untuk mengeksekusi suatu komitmenpada tingkat minimum pinjaman yang macet atas kinerja melalui tingkat pengembalian aset / return on assets (ROA) (Olalekan, Olumide, \& Irom, 2018). Temuan penelitian ini sejalan dengan beberapa penelitian yang direviu atas pengaruh negatif risiko kredit terhadap profitabilitas tetapi tidak secara signifikan (Sisay, 2017; Olalekan, Olumide, \& Irom, 2018; Suryo, Rahayu, \& Nurbaiti, 2016). Penelitian ini juga tidak membuktikan teori pensinyalan bagi investor atas keputusan investasi terkait dengan risiko keuangan sehubungan dengan tingkat kredibilitas perusahaan.

b. Hipotesis alternatif ke-2 menyatakan bahwa Risiko Solvabilitasberpengaruh negatif terhadap Profitabilitas Perusahaan memiliki koefisien regresi $\beta 2$ sebesar -0,216 dengan probabilitas signifikansi sebesar 0,007. Hasil pengujian hipotesis menunjukkan bahwa Risiko Solvabilitas yang diukur berdasarkan risk-based capital(RBC) terbukti berpengaruh negatif terhadap Profitabilitas Perusahaan. Risiko solvabilitasterbukti instrumen untuk mengukur solvabilitas dan tolok ukur atas kepentingan nasabah khususnya pada perusahaan-perusahaan asuransi berdasarkan Salinan POJK dinyatakan bahwa Target Tingkat Solvabilitas internal ditetapkan paling rendah $120 \%$ (seratus dua puluh persen) dari MMBR (OJK, 2016), hal ini diperkuat dengan analisisstatistik deskriptif dengan skor RBC130,87 persen. Temuan penelitian ini sejalan dengan beberapa penelitian yang direviu atas pengaruh negatif risiko solvabilitas terhadap profitabilitas secara signifikan (Wani \& Dar, 2015; Ullah, Faisal, \& Zuhra, 2016; Bogar, 2016; Sisay, 2017).

c. Hipotesis alternatif ke-3 menyatakan bahwa Kualitas Auditberpengaruh positif terhadap Profitabilitas Perusahaan memiliki koefisien regresi $\beta 3$ sebesar - 0,750 dengan probabilitas signifikansi sebesar 0,033. Hasil pengujian hipotesis menunjukkan bahwa Kualitas Audit yang diukur berdasarkan kategori KAP Big-Four dan selain Big-Fourtidak terbukti berpengaruh negatifmelainkan berpengaruh positif terhadap Profitabilitas Perusahaan. Seorang auditor dituntut untuk memiliki independensi, kompetensi dan pertimbangan profesional dalam menilai keadaan entitas dan penilaian risiko perusahaan berdasarkan Generally Accepted Accounting Principles (GAAP) dalam bentuk opini atas laporan keuangan perusahaan yang dirilis oleh KAP. Berdasarkan datastatistik deskriptif hanya 28 persen perusahaan yang menjadi sampel dalam penelitian ini diaudit oleh KAP Big-Four. Temuan penelitian ini dengan penelitian yang direviu yang membuktikan pengaruh positif audit eksternal terhadap kesehatan keuangan perusahaan (Merawati \& Hatta, 2014).

d. Hipotesis alternatif ke-4 menyatakan bahwa Profitabilitas Perusahaan berpengaruh positif terhadap Kualitas Laba memiliki koefisien regresi $\beta 4$ sebesar 0,000 dengan probabilitas signifikansi sebesar 0,999. Hasil pengujian hipotesis menunjukkan bahwa Profitabilitas Perusahaan yang diukur dengan return on equity terbukti berpengaruh positif tetapi tidak signifikan terhadap Kualitas Laba. Temuan penelitian ini bertolak belakang dengan penelitian yang membuktikan pengaruh positif profitabilitas dan nilai perusahaan terhadap praktik perataan laba (Lathifah, Hidayati, \& Malikah, 2018) sementara juga bertolak belakang dengan penelitian yang membuktikan pengaruh negatif profitabilitas yang diukur 
dengan return on assets terhadap kualitas laba dengan proksi total akrual (Laoli \& Herawaty, 2019)

e. Hipotesis alternatif ke-5, ke-6, dan ke-7 menyatakan bahwa Risiko Kredit, Risiko Solvabilitas dan Kualitas Audit berpengaruh negatif terhadap Kualitas Laba memiliki koefisien regresi $\beta 5, \beta 6$ dan $\beta 7$ masing-masing sebesar $-0,820,-0,025$ dan $-0,066$ dengan probabilitas signifikansi masing-masing sebesar 0,369, 0,632 dan 0,771. Hasil pengujian hipotesis menunjukkan bahwa Risiko Kredit, Risiko Solvabilitas dan Kualitas Audit terbukti berpengaruh negatif tetapi tidak signifikan terhadap Kualitas Laba. Temuan penelitian bahwa risiko keuangan dengan proksi leverage sejalan dengan tidak signifikannya terhadap kualitas laba dengan pendekatan perataan laba (Lathifah, Hidayati, \& Malikah, 2018). Sementara variabel Risk Based Capital (RBC) tidak berpengaruh signifikan terhadap kinerja keuangan (Sumartono \& Harianto, 2018) dan kualitas audit pada penelitian ini dengan proksi Big Four dan selain Big Four sejalan dengan tidak signifikannya terhadap kualitas laba dengan pendekatan discretionary accruals (DA) (Ulina, Mulyadi, \& Tjahjono, 2018) sementara bertolak belakang dengan pengaruh positif kualitas audit terhadap kualitas laba (Aryengki, Satriawan, \& Rofika, 2016).

f. Hipotesis alternatif ke-8, ke-9, dan ke-10 menyatakan bahwa Risiko Kredit, Risiko Solvabilitas dan Kualitas Audit yang dimediasi oleh Profitabilitas Perusahaan terhadap Kualitas Laba memiliki koefisien regresi $\beta 8, \beta 9$ dan $\beta 10$ masing-masing sebesar $-1,195$, 0,1250 dan -0,4902 dengan probabilitas signifikansi masing-masing sebesar 0,8815, 0,7914 dan 0,8056. Hasil pengujian hipotesis menunjukkan bahwa Risiko Kredit dan Risiko Solvabilitas. Sementara kualitas audit juga tidak dimediasi oleh Profitabilitas Perusahaan terhadap Kualitas Laba yang juga sejalan dengan tidak dibuktikan oleh variabel kualitas audit yang menjadi prediktor dalam pengukuran book-tax differences terhadap kualitas laba (Ritonga, 2019).

Berdasarkan hasil uji koefisien determinasi total $\left(\mathrm{Rm}^{2}\right)$ memberikan informasi untuk mengukur kekuatan pengaruh variabel-variabel yang diteliti terhadap profitabilitas serta implikasinya pada kualitas laba dari kedua model regresi. Hasil perhitungan yang diperoleh dari Tabel 7 menunjukkan skor koefisien determinasi sebesar 0,2111 atau hanya 21,11 persen variabel dependen tersebut dipengaruhi oleh faktor risiko keuangan yaitu risiko kredit dan solvabilitas serta faktor kualitas audit sementara sisanya 78,89 persen dipengaruhi oleh faktor lain yang tidak diuji ke dalam model penelitian ini. Hasil analisis ini dapat dinyatakan bahwa pengaruh Risiko Kredit, Risiko Solvabilitas dan Kualitas Audit terhadap Profitabilitas Perusahaan serta Implikasinya terhadap Kualitas Laba pada perusahaan sektor keuangan sub sektor asuransi umum yang terdaftar di BEI (Bursa Efek Indonesia) tahun 2014-2018 dengan model yang sangat terbatas.

\section{SIMPULAN, KETERBATASAN DAN SARAN}

Risiko kredit dengan pendekatan credit risk yang menggambarkan risiko kemungkinan adanya kehilangan atau penurunan nilai aset yang disebabkan oleh kegagalan debitur tidak berpengaruh signifikan baik secara langsung maupun yang dimediasi oleh profitabilitas perusahaan terhadap kualitas laba.Risiko solvabilitas dengan pendekatan risk-based capital (RBC) yang menggambarkan risiko kemungkinan yang timbul sebagai akibat dari deviasi dalam pengelolaan kekayaanberpengaruh negatifterhadap profitabilitas perusahaan tetapi tidak berpengaruh signifikan terhadap kualitas laba secara langsung maupun yang dimediasi oleh profitabilitas perusahaan terhadap kualitas laba. Kualitas audit dengan pengukuran kategori KAP Big-Four dan selain Big-Four berpengaruh negatifterhadap profitabilitas perusahaan 
tetapi tidak berpengaruh signifikan terhadap kualitas laba secara langsung maupun yang dimediasi oleh profitabilitas perusahaan terhadap kualitas laba.

Penentuan sampel hanya terbatas pada sub sektor asuransi kategori umum yang lingkupnya sangat sempit dibandingkan dengan sektor keuangan dan keseluruhan perusahaan yang listing di Bursa Efek Indonesia (BEI) sehingga hasil penelitian ini tidak dapat digeneralisasi untuk perusahaan-perusahaan asuransi di Indonesia, hasil penelitian ini juga dibuktikan dengan koefisien determinasi total $\left(\mathrm{Rm}^{2}\right)$ sebesar 0,2111 yang artinya masih banyak terdapat faktor-faktor lain yang tidak dilibatkan pada penelitian ini. Di samping itu, pada model pengukuran profitabilitas perusahaan dan kualitas laba menggunakan pendekatan ROE dan distribusi laba yang cenderung menghasilkan pengukuran yang sama sehingga hasil penelitian yang dimediasi oleh profitabilitas perusahaan juga tidak mampu membuktikan signifikansi temuan penelitian.

Agenda pada penelitian mendatang diharapkan dapat memperluas lingkup penelitian pada sektor lainnya dan pengukuran profitabilitas perusahaan menggunakan pengukuran selain return on equity (ROE) serta menggunakan pengukuran kualitas laba dengan pendekatan lainnya seperti kualitas akrual (accruals quality), persistensi (persistence), prediktabilitas (predictability), smoothness, value relevance, timeliness dan conservatism (Dechow, Ge, \& Schrand, 2010). Penambahan faktor-faktor lain untuk memprediksi Profitabilitas perusahaan serta dampaknya atas Kualitas Laba seperti pengukuran rasio keuangan serta faktor risiko dalam perhitungan MMBR pada Pasal 3 ayat (1) tentang Kesehatan Keuangan perusahaan Asuransi dan Perusahaan Reasuransi yaitu risiko kredit, risiko likuiditas, risiko pasar, risiko asuransi dan risiko operasional (OJK, 2016).

\section{UCAPAN TERIMA KASIH}

Saya mengucapkan terima kasih pada Allah SWT atas rahmat dan karunia-Nya sehingga artikel ini dapat diselesaikan. Penulis juga mengucapkan terima kasih kepada Institut Teknologi dan Bisnis Ahmad Dahlan serta Universitas Multimedia Nusantara yang memberi kesempatan untuk melakukan penelitian serta masukan-masukan dalam penyempurnaan isi artikel mengenai Risiko Keuangan, Profitabilitas dan Kualitas Laba Perusahaan.

\section{REFERENSI}

Al Hafiz, M. P. (2018, Januari 11). Asuransi Jiwa Pada Tahun 2018, Masih Prospektif. Dipetik Januari 25, 2020, dari Marketeers \#1 Marketing Media \& Mice: https://marketeers.com/54146-2/

Aldila, N., Jatmiko, L. D., \& Hana, O. D. (2019, Pebruari 28). Rapor Merah Asuransi

Jiwa: Terburuk 5 Tahun Terakhir. Dipetik Januari 25, 2020, dari https://finansial.bisnis.com/read/20190228/215/894490/rapor-merah

Aryengki, R., Satriawan, R. A., \& Rofika. (2016). Pengaruh Komite Audit, Kualitas Audit, Likuiditas Dan Ukuran Perusahaan Terhadap Kualitas Laba Pada Perusahaan Industry \& Chemical Yang Terdaftar Di Bursa Efek Indonesia Tahun 2011-2014. JOM Fekon , 3 (1), 2192-2206.

Bank Indonesia. (2019). Statistik Ekonomi dan Keuangan Indonesia (SEKI). Jakarta.

Baskoro, F. M. (2018, Pebruari 15). Bagaimana Nasib Agen Asuransi di Era Revolusi Industri 4.0? Dipetik Januari 26, 2020, dari https://www.beritasatu.com/ekonomi/478733/bagaimana-nasib-agen-asuransi-di-era-revolusiindustri-40

Bogar, S. (2016). Analisis Risk Base Capital (RBC) di Perusahaan Asuransi. JRAK: Jurnal Riset Akuntansi dan Komputerisasi Akuntansi , 7 (2), 54-70. 
Brigham, E. F., \& Houston, J. F. (2014). Dasar-Dasar Manajemen Keuangan. Jakarta: Salemba Empat.

Dalimunthe, D. A. (2019, Agustus 20). Meski bisnis asuransi tumbuh 20,6\%, AAUI akui masih ada tantangan hingga akhir tahun. (Yoyok, Penyunt.) Dipetik Januari 25, 2020, dari https://keuangan.kontan.co.id/news/meski-bisnis-asuransi-tumbuh-206-aaui-akui-masih-adatantangan-hingga-akhir-tahun

Dechow, P. M., Ge, W., \& Schrand, C. M. (2010). Understanding Earnings Quality: A Review of the Proxies, Their Determinants and Their Consequences. Journal of Accounting and Economics , 50 (2-3), 344-401.

Ghozali, I. (2017). Aplikasi Analisis Multivariate Dengan Program: IBM SPSS 23 (VIII ed.). Semarang: Badan Penerbit UNDIP.

Indrawati. (2015). Metode Penelitian Manajemen dan Bisnis Konvergensi Teknologi Komunikasi dan Informatika. Bandung: PT.Refika Aditama.

Intan, N. (2019, Maret 12). OJK: Investor Asing Gencar Masuk Pasar Asuransi Indonesia. (N. Zuraya, Editor) Retrieved Januari 25, 2020, from Republika Berita Ekonomi: https://www.republika.co.id/berita/ekonomi/ keuangan/19/03/12/po92ca383-ojk-investorasing-gencar-masuk-pasar-asuransi-indonesia

Kasmir, D. (2016). Analisis Laporan Keuangan. Jakarta: PT. Rajagrafindo Persada.

Laoli, A. N., \& Herawaty, V. (2019). Pengaruh Profitabilitas, Growth, Leverage, Operating Cycle Dan Preduence Terhadap Kualitas Laba Dengan Firm Size Sebagai Variabel Moderasi. Seminar Nasional Cendekiawan ke-5 Tahun 2019, Buku 2: "Sosial dan Humaniora“ (hal. 2.39.1-7). Jakarta: Lemlit Universitas Trisakti.

Lathifah, Hidayati, H. N., \& Malikah, H. A. (2018). Pengaruh Risiko Keuangan, Profitabilitas, dan Nilai Perusahaan terhadap Praktik Perataan Laba (Income Smoothing) (Studi Empiris Terhadap Perusahaan Manufaktur Yang Terdaftar di BEI Tahun 2013-2015). 96-110.

Lokobal, A. M. (2014). Manajemen Risiko Pada Perusahaan Jasa Pelaksana Konstruksi di Propinsi Papua (Study Kasus Di Kabupaten Sarmi). Jurnal Ilmiah Media Engineering , 42, 109-118.

Merawati, E. E., \& Hatta, I. H. (2014). Pengaruh Pengawasan Komite Audit, Audit Internal, Audit Eksternal terhadap Kesehatan Keuangan Perusahaan dan Dampaknya terhadap Profitabilitas. Jurnal Akuntansi , XVIII (03), 335-349.

Nurfadila, S., Hidayat, R. R., \& Sulasmiyati, S. (2015). Analisis Rasio Keuangan Dan Risk Based Capital Untuk Menilai Kinerja Keuangan Perusahaan Asuransi (Studi Pada PT. Reasuransi Indonesia (Persero) Periode 2011-2013. Jurnal Administrasi Bisnis (JAB) , 22 (1), 2-9.

Oh, H., Park, S., \& Hong, S. (2016). Effect of Corporate Governance on The Association between Book-Tax Differences and Audit Quality: Evidence from Korea. The Journal of Applied Business Research , 32 (4), 1097-1114.

OJK. (2017). Lampiran Surat Edaran Otoritas Jasa Keuangan Nomor 24/ SEOJK.05/2017 tentang Pedoman Perhitungan Jumlah Modal Minimum Berbasis Risiko Bagi Perusahaan Asuransi dan Perusahaan Reasuransi.

OJK. (2016). Peraturan Otoritas Jasa Keuangan Nomor 71/ POJK.05/2016 tentang Kesehatan Keuangan Perusahaan Asuransi dan Perusahaan Reasuransi.

Olalekan, L. I., Olumide, M. L., \& Irom, M. (2018). Financial Risk Management and The Profitability An Empirical Evidence from Commercial Banks in Nigeria. Sahel Analyst: Journal of Management Sciences , 16 (2), 117-137.

Phillips, J., Pincus, M., \& Rego, S. O. (2003). Earnings Management: New Evidence Based on Deferred Tax Expense. The Accounting Review , 78 (2), 491-521. 
Ritonga, P. (2019). Pengaruh Book-Tax Differences Terhadap Earnings Quality serta Implikasinya pada Audit Quality. Forum Bisnis Dan Kewirausahaan (Forbiswira) , 9 (1), 2334.

Sisay, D. (2017). The Effect of Financial Risk on Perfomance of Insurance Companies in Ethiopia. School of Graduates Studies, Accounting \& Finance. Ethiopia: Addis Ababa University.

Solomon, D. C., Muntean, M., \& Alecsandri, V. (2012). Assessment of Financial Risk in Firm's Profitability Analysis. Economy Transdisciplinarity Cognition , 15 (2), 58-67.

Subramanyam, K. (2014). Financial Statement Analysis (11th International Edition ed.). New York: McGraw-Hill.

Sugiyono. (2018). Metode Penelitian Evaluasi: Pendekatan Kuantitatif, Kualitatif, dan Kombinasi. Bandung: CV. Alfabeta.

Sumartono, \& Harianto, K. A. (2018). Kinerja Keuangan Perusahaan Asuransi Di Indonesia dan Faktor-faktor yang Mempengaruhinya. Future Jurnal Manajemen dan Akuntansi , 6 (1), 1-14.

Sumomba, C. R., \& Hutomo, Y. S. (2012). Pengaruh Beban Pajak Tangguhan dan Perencanaan Pajak Terhadap Manajemen Laba. KINERJA , 16 (2), 103-115.

Surifah. (2010). Kualitas Laba dan Pengukurannya. Jurnal Ekonomi, Manajemen \& Akuntansi , 8 (2), 31-47.

Suryo, M. G., Rahayu, S., \& Nurbaiti, A. (2016). Pengaruh Risiko Kredit, Risiko Likuiditas Dan Risiko Tingkat Bunga Terhadap Profitabilitas (Studi Pada Perbankan yang Terdaftar di Bursa Efek Indonesia Tahun 2011-2015). e-Proceeding of Management, 3, hal. 3450-3457.

Suud, C. F. (2016). Pengaruh Underwriting dan Solvabilitas terhadap Laba Perusahaan Reasuransi. Skripsi, Universitas Lampung, Fakultas Ekonomi dan Bisnis, Bandar Lampung.

Tandiontong, M. (2016). Kualitas Audit dan Pengukurannya. Bandung: Lafabeta.

The National Bank of Ethiopia (NBE). (2010). Risk Management Guideline for insurance Companies in Ethiopia. Retrieved Januari 25, 2020, from Addis Ababa: https://nbebank.com/wp-content/uploads/2019/04/insurance-busines.pdf

Ulina, R., Mulyadi, R., \& Tjahjono, M. E. (2018). Pengaruh Kualitas Audit dan Komite Audit Terhadap Manajemen Laba Pada Perusahaan Manufaktur Yang Tercatat Di Bursa Efek Indonesia. Tirtayasa EKONOMIKA, 13 (1), 1-26.

Ullah, G. M., Faisal, M. N., \& Zuhra, S. T. (2016). Factors Determining Profitability of the Insurance Industry of Bangladesh. International Finance and Banking, 3 (2), 138-147.

Wani, A. A., \& Dar, D. S. (2015). Relationship between Financial Risk and Financial Performance: An Insight of Indian Insurance Industry. International Journal of Science and Research (IJSR) , 4 (11), 1424-1433.

Worku, A., \& Asmare, A. (2018). Determinants of Micro-Insurance Business Performance in Ethiopia. Journal of Accounting, Finance and Auditing Studies , 4 (4), 160-172. 